\title{
Field Evaluation of the Effectiveness of Thermotherapy against Cassava Mosaic Disease in Central African Republic
}

\author{
Innocent Zinga ${ }^{1,2,3^{*}}$, Frédéric Chiroleu ${ }^{1}$, Emmanuel Kamba ${ }^{2}$, \\ Charlotte Giraud-Carrier ${ }^{1}$, Mireille Harimalala ${ }^{1}$, Ephrem Kosh Komba ${ }^{2}$, \\ Simplice Yandia ${ }^{2}$, Silla Semballa ${ }^{2}$, Bernard Reynaud ${ }^{1}$, \\ Jacques Dintinger ${ }^{1}$, Pierre Lefeuvre ${ }^{1}$ and Jean-Michel Lett ${ }^{1}$ \\ ${ }^{1}$ CIRAD, UMR PVBMT, Plant Protection Center, 97410 Saint-Pierre, Reunion Island, France. \\ ${ }^{2}$ Laboratory of Biological and Agricultural Sciences for Development (LBSAD), University of \\ Bangui, BP908 Bangui, Central African Republic. \\ ${ }^{3}$ University of Reunion, UMR PVBMT, Plant Protection Center, 97410 Saint-Pierre, \\ Reunion Island, France.
}

\section{Authors' contributions}

This work was carried out in collaboration between all authors. Authors IZ, FC, SS, BR, JD, $P L$ and JML designed the study and wrote the protocol. Authors IZ, EK, MH, EKK, SY managed the experiments. Authors IZ, FC and CGC performed the statistical analysis. Authors IZ, FC, PL and JML wrote the manuscript. All authors read and approved the final manuscript.

\section{ABSTRACT}

Aim: The effectiveness of thermotherapy in managing cassava mosaic disease (CMD) was studied on a susceptible local cultivar in the field in the epidemiological conditions.

Study Design: The field was laid out in randomized complete block design

Place and Duration: Field experiment was conducted in forest zone at Kapou located in south west of Central African Republic according to University of Bangui during August 2010 and July 2011.

Methodology: Diseased cassava cuttings were treated in a heated water bath at temperatures ranging from $43^{\circ} \mathrm{C}$ to $51^{\circ} \mathrm{C}$ for 30 min before being grown for 12 months in the field. 
Results: Temperatures from $43^{\circ} \mathrm{C}$ to $49^{\circ} \mathrm{C}$ were found to have no deleterious effect on either the survival of cuttings or on plant regeneration. One month after planting (MAP), up to $40 \%$ of the cuttings treated at $47^{\circ} \mathrm{C}$ to $49^{\circ} \mathrm{C}$ had regenerated a plant with no CMD symptoms compared to $7 \%$ of untreated cuttings. Between two and five MAP, cassava cuttings treated at $49^{\circ} \mathrm{C}$ produced plants with a significantly lower incidence of CMD than plants produced from untreated cuttings. All plants grown from treated cuttings developed significantly less severe CMD symptoms than untreated cuttings between 8 and 12 months after planting. The highest tuberous root yield was obtained with diseased cuttings treated at $49^{\circ} \mathrm{C}(4.7 \mathrm{~kg} / \mathrm{plant})$, equivalent to the yield from untreated symptomless cuttings (4.6kg/plant).

Conclusion: Our data clearly demonstrate the value of thermotherapy to maintain a high level of production using local cultivars under severe CMD epidemic conditions.

Keywords: Manihot esculenta; cassava mosaic disease; sanitation; thermotherapy; incidence; severity and yield; Central African Republic.

\section{INTRODUCTION}

Cassava (Manihot esculenta Crantz, Family Euphorbiaceae) is one of the most cultivated and the most consumed crop in sub-Saharan Africa [1]. However, cassava mosaic disease (CMD), transmitted by the whitefly Bemisia tabaci (Gennadius) and perpetuated through cuttings, causes severe losses annually in all cassava-growing areas of Africa. Of the 134 million tonnes of tuberous roots produced in Africa in 2010, annual loss was estimated to be 35 million tonnes [1]. Except the recent cassava brown streak disease epidemic in East Africa [2], CMD is the principal limitation factor for cassava cultivation in tropical and subtropical regions in Africa $[3,4,5,6,7,8,9]$.

Several studies have demonstrated that phytosanitation measures that improve the healthstatus of cassava planting materials contribute to improve the cassava production in Africa $[10,11,12,13,14,15]$. Thermotherapy technique coupled with tissue culture, to cure the infected plants, have been carried out in the $70 \mathrm{~s}$ in several countries [10]. In Nigeria, meristem tips from diseased cassava plants subjected to heat treatment at $35-38^{\circ} \mathrm{C}$ for 30 days were found healthy by visual inspection of the leaves [16]. In Ghana, similar results were obtained with CMD plants treated at $37^{\circ} \mathrm{C}$ for 30 days [15]. Thermotherapy performed directly on the cuttings from plants affected with CMD was initiated in Kenya [1]. After hot-air treatment of plants contaminated with $\mathrm{CMD}$ at $37^{\circ} \mathrm{C}$ for 87 to 105 days, the pathogen was eradicated from 33 to $44 \%$ of tip cuttings $(1.0-1.5 \mathrm{~cm}$ long). However, they concluded that hot-water treatments of diseased stem cuttings, at 50 or $55^{\circ} \mathrm{C}$ for varying intervals, were not therapeutic.

Temperature dramatically affects plant-virus interactions with an attenuation of virus-induced symptoms at high temperature [17]. Consequently, thermotherapy has been considered as a first-choice method to free vegetative material from viruses [18]. It was demonstrated that the underlying molecular mechanism behind the effect of temperature on symptom severity of Cymbidium ring spot virus (CymRSV; an RNA virus) was associated with gene silencing. The increase in temperature leads to an increase in virus-derived siRNA accumulation, resulting in the development of fewer symptoms [17]. Cassava geminivirus-induced RNA silencing was also found to be increased by raising the temperature from $25^{\circ} \mathrm{C}$ to $30^{\circ} \mathrm{C}$, with 
the appearance of asymptomatic newly developed leaves, irrespective of the nature of the virus [19].

In Central African Republic (CAR) cassava is the first food crop with 2.4 million tonnes of fresh tuberous roots, equivalent to 600,000 tonnes of chips, ten times higher than maize and groundnuts [20]. Both tuberous roots and leaves are eaten, the former as a major source of carbohydrates and the latter as green vegetable providing vitamins, minerals and proteins [21]. Disease surveys conducted in CAR between 2005 and 2008 have reported $85 \%$ incidence of CMD with a yield loss estimated at 50\% [8,22]. Importantly, these studies also demonstrated that $79 \%$ of the cuttings used by farmers for cultivation were contaminated with CMD. Molecular characterization of the viruses involved also showed that the causal agents of CMD in CAR were the African cassava mosaic virus (ACMV) and the Uganda strain of East African cassava mosaic virus (EACMV-UG), with $58 \%$ of diseased samples presenting mixed infections with higher symptom severities [22,23]. Even if management efforts to control CMD have mainly focused on multiplication and dissemination of resistant varieties [9], the application of phytosanitation deserve further research.

This paper presents results on the study of the effectiveness of thermotherapy in managing CMD in the field and under Central African Republic epidemiological conditions. Particular attention was paid to the identification of cheap and readily applied management measures that could be popularized in rural areas.

\section{MATERIALS AND METHODS}

\subsection{Experimental Site}

The experimental site is located at Kapou, $40 \mathrm{~km}$ south of Bangui in the Guinean forest zone $\left(04^{\circ} 13^{\prime} 425 \mathrm{~N} ; 18^{\circ} 18^{\prime} 034 \mathrm{E} ; 255 \mathrm{~m}\right.$ altitude) characterized by an annual mean temperature of $25^{\circ} \mathrm{C}$ with a rainy season between May and October and a dry season between November and April. Annual mean rainfall is $1600 \mathrm{~mm}$. The study period was August 2010 to July 2011 corresponding to a complete cultivation cycle.

\subsection{Plant Material}

Cuttings from the local CMD-susceptible cultivar "Yalipé" showing CMD symptoms with a severity score of 3 [24] and symptomless cuttings from the same cultivar were collected in cassava fields at Damara. Selection of stem cuttings for use as planting material was based on the visual assessment of the standing plants.

\subsection{Experimental Design}

Two hundred diseased cuttings $30 \mathrm{~cm}$ in length were split into five lots (40x5), corresponding to five temperature treatments. Each set was treated in a heated-water bath at $43^{\circ} \mathrm{C}$ (T1), $45^{\circ} \mathrm{C}(\mathrm{T} 2), 47^{\circ} \mathrm{C}(\mathrm{T} 3), 49^{\circ} \mathrm{C}(\mathrm{T} 4)$ or $51^{\circ} \mathrm{C}$ (T5) for 30 minutes. Three batches of 40 cuttings (untreated controls) were included in the experimental design: (i) A diseased Yalipé cultivar control, (ii) A symptomless Yalipé cultivar control, and (iii) A cassava cultivar from Reunion Island free from CMD as a healthy control. All the cuttings were planted in a complete randomized block design in the open field with $1 \mathrm{~m} \times 1 \mathrm{~m}$ spacing. 


\subsection{Assessment of Thermotherapy}

For each plant, CMD incidence, a CMD symptom severity score, and the abundance of whiteflies were recorded on the five top youngest leaves monthly for one to 12 months after planting (MAP), based on the standard protocols established by Sseruwagi team [25]. CMD incidence was calculated as the proportion of plants with symptoms. The CMD symptom severity score was rated on a six-point scale [25]: 0, no symptoms; 1 , mild chlorosis without leaf deformation; 2, visible mosaic with or without slight leaf deformation; 3 , strong mosaic all over the leaflets with deformation; 4 , as in 3 but with severe leaf deformation; and 5 , severe mosaic and severe reduction of leaf size. The weight of tuberous roots was recorded 12 MAP (July 2011) at harvest. The yield was estimated as the average weight in $\mathrm{kg}$ of fresh tuberous roots per plant and per treatment.

\subsection{Statistical Analyses}

Data processing and analysis were performed using $R$ software (version 2.15.3, $R$ Development Core Team, 2013). A pairwise Fisher's exact test with a Holm's correction [26] was used to compare the effect of the thermotherapy on percentage plant regeneration, and on monthly incidence. The effect of treatment on the monthly symptom severity score was tested by a proportional odds logistic regression model. The effect of the treatment on the mean weight of tuberous roots was tested by analysis of variance; the weights were logtransformed to take into account the heteroscedasticity of residuals. A Tukey's test of pairwise mean comparisons was then used to compare mean yields between treatments. All the tests were performed at a level of significance of $\mathrm{P}=0.05$.

\section{RESULTS AND DISCUSSION}

\subsection{Results}

\subsubsection{Abundance of white fly vectors}

The number of whiteflies observed on plants was low (1-3 whiteflies) during the first three months of the experiment and thereafter gradually increased to reach a first peak at 7 MAP (22-28 whiteflies during the dry season) and then a second peak at 11 MAP (10-18 whiteflies during the rainy season; Fig. 1). Importantly, no difference in the mean number of whiteflies was observed between untreated and treated plants.

\subsubsection{Effect of thermotherapy on plant regeneration}

Temperatures from $43^{\circ} \mathrm{C}$ to $49^{\circ} \mathrm{C}$ ( $\mathrm{T} 1$ to $\mathrm{T} 4$ ) had no significant deleterious effect on the survival of cuttings and regeneration of cassava plants with nearly $100 \%$ of plants regenerated, while only $80 \%$ of the cuttings treated at $51^{\circ} \mathrm{C}(\mathrm{T} 5)$ regenerated cassava plants (significantly different from other treatments, $\mathrm{P}<0.001$ ). 


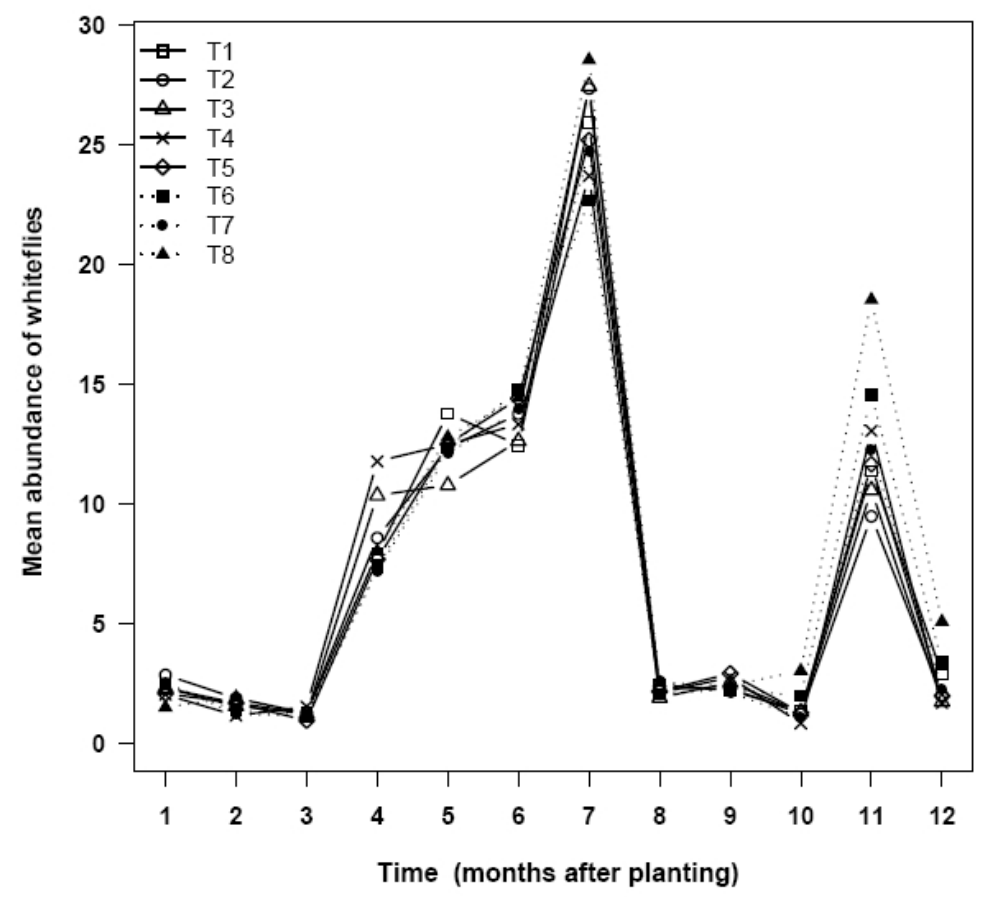

Fig. 1. Average number of whiteflies per cassava plant in heat-treated cassava mosaic diseased cuttings of a local cv. 'Yalipé' in the 12 months after planting at Kapou in the Central African Republic (2010/2011)

T1: diseased cuttings treated at $43^{\circ} \mathrm{C}, T 2: 45^{\circ} \mathrm{C}, T 3: 47^{\circ} \mathrm{C}, T 4: 49^{\circ} \mathrm{C}, \mathrm{T5}: 51^{\circ} \mathrm{C}, \mathrm{T6}$ : untreated diseased cuttings, T7: untreated symptomless cuttings, and T8: healthy cassava cv. from Reunion Island free from CMD used as control

\subsubsection{CMD incidence}

One month after planting, statistical analysis revealed the lowest CMD incidence on untreated symptomless cuttings $(T 7,23 \%)$ and untreated healthy cuttings from Reunion Island (T8, 5\%). The highest CMD incidence was observed on plants grown from untreated diseased cuttings (T6,93\%), diseased cuttings treated at $43^{\circ} \mathrm{C}(\mathrm{T} 1,88 \%)$ and $45^{\circ} \mathrm{C}(\mathrm{T} 2$, $85 \%)$ Fig. 2. Moderate CMD incidence was observed on plants grown from diseased cuttings treated at $47^{\circ} \mathrm{C}(\mathrm{T} 3,61 \%), 49^{\circ} \mathrm{C}(\mathrm{T} 4,59 \%)$, and $51^{\circ} \mathrm{C}(\mathrm{T} 5,57 \%)$. Highly significant differences in CMD incidence were observed between the untreated diseased cuttings (T6) and the diseased cuttings treated at $47^{\circ} \mathrm{C}(\mathrm{T} 3, \mathrm{P}=0.0019), 49^{\circ} \mathrm{C}(\mathrm{T} 4, \mathrm{P}=0.0006)$ and $51^{\circ} \mathrm{C}$ (T5, $P=0.0016)$. Although the incidence of $C M D$ on these plants reached $100 \%$ at eight MAP, only the plants regenerated from diseased cuttings treated at $49^{\circ} \mathrm{C}$ (T4) presented significantly lower CMD incidence $(P<0.001)$ than the untreated control $(T 6)$ between two and five MAP, suggesting that $49^{\circ} \mathrm{C}$ is the most effective temperature to reduce the incidence of the disease. The rapid increasing CMD incidence (from 5\% to 100\%) on the Reunion cultivar during the first three months of the growth confirmed the high susceptibility of this cultivar to CMD and the serious constraint of this disease in the Central African Republic even in the case of a low abundance of whiteflies. 


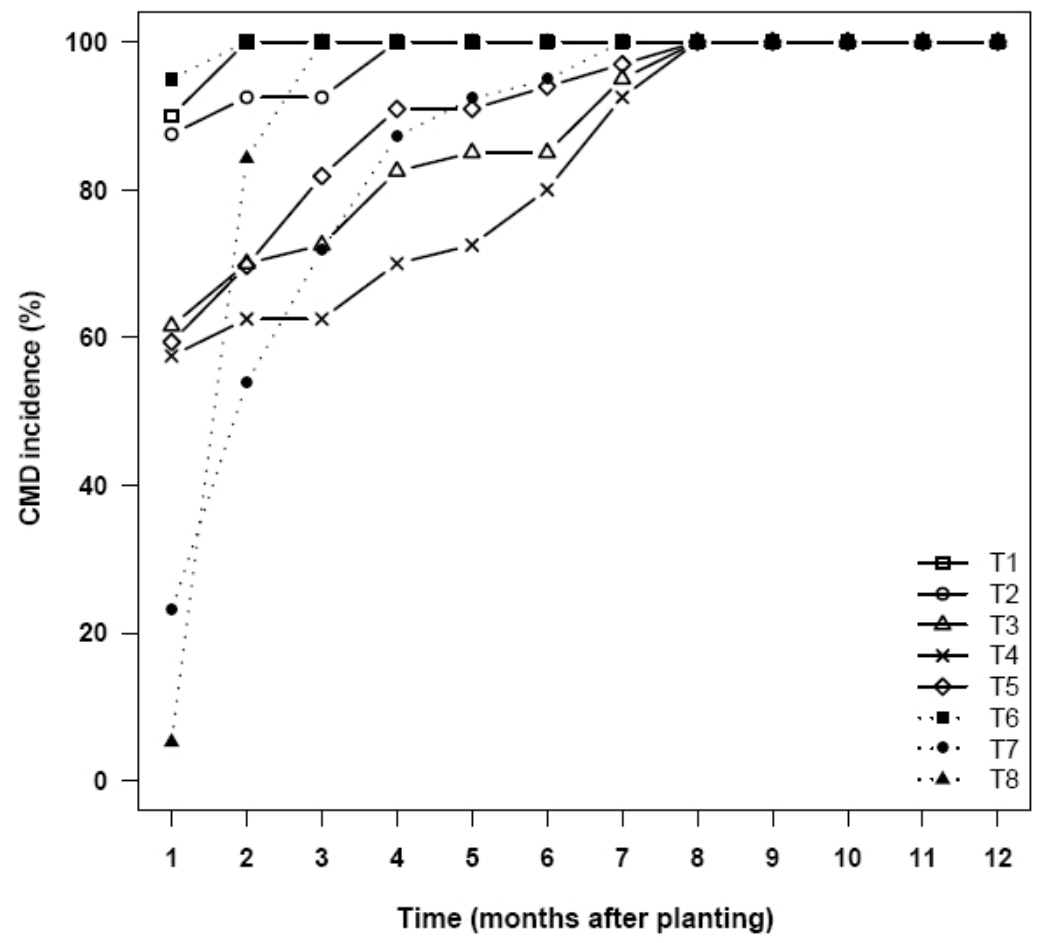

Fig. 2. Incidence of cassava mosaic disease (CMD, percentage of symptomatic plants) in heat-treated diseased cuttings of a local cv. 'Yalipé' in the 12 months after planting at Kapou in the Central African Republic (2010/2011) cassava cv. from Reunion Island free from CMD used as control

T1: diseased cuttings treated at $43^{\circ} \mathrm{C}, T 2: 45^{\circ} \mathrm{C}, T 3: 47^{\circ} \mathrm{C}, T 4: 49^{\circ} \mathrm{C}, T 5: 51^{\circ} \mathrm{C}, \mathrm{T}$ : untreated diseased cuttings, T7: untreated symptomless cuttings, and T8: healthy cassava cv. from Reunion Island free from CMD used as control

\subsubsection{CMD symptom severity}

At 12 MAP, the plants grown from treated diseased cuttings (T1 to T5) had significantly lower mean scores for CMD symptom severity than those for untreated diseased cuttings (T6) $(P<0.05)$, suggesting that heat treatment of cuttings can significantly reduce the expression of CMD symptoms Fig. 3. Specifically, compared with untreated diseased cuttings (T6), significantly lower mean scores of CMD symptom severity were observed from the fourth month of growth for the plants regenerated from diseased cuttings treated at $47^{\circ} \mathrm{C}$ (T3), from the eighth and ninth months of growth respectively for treatments at $45^{\circ} \mathrm{C}$ (T2) and $49^{\circ} \mathrm{C}$ (T4) and finally, from the 11th and 12th months of growth respectively for treatments at $51^{\circ} \mathrm{C}(\mathrm{T} 5)$ and $43^{\circ} \mathrm{C}(\mathrm{T} 1)(\mathrm{P}<0.05)$.

\subsubsection{Weight of tuberous roots}

The highest mean weight of tuberous roots per plant was obtained with plants grown from untreated symptomless cuttings $(T 7,4.6 \mathrm{~kg} / \mathrm{plant})$ and from diseased cuttings treated at $49^{\circ} \mathrm{C}$ (T4, 4.7kg/plant) Fig. 4. These weights were significantly higher $(P<0.05)$ than those obtained from plants grown from diseased cuttings treated at $47^{\circ} \mathrm{C}(\mathrm{T} 3,3.11 \mathrm{~kg} / \mathrm{plant})$, 
untreated diseased cuttings ( $\mathrm{T} 6,2.8 \mathrm{~kg} / \mathrm{plant})$, diseased cuttings treated at $45^{\circ} \mathrm{C}(\mathrm{T} 2,2.5$ $\mathrm{kg} /$ plant $)$ and at $43^{\circ} \mathrm{C}(\mathrm{T} 1,2.3 \mathrm{~kg} / \mathrm{plant})$, and untreated healthy cuttings from Reunion Island (T8, 2.09kg/plant).

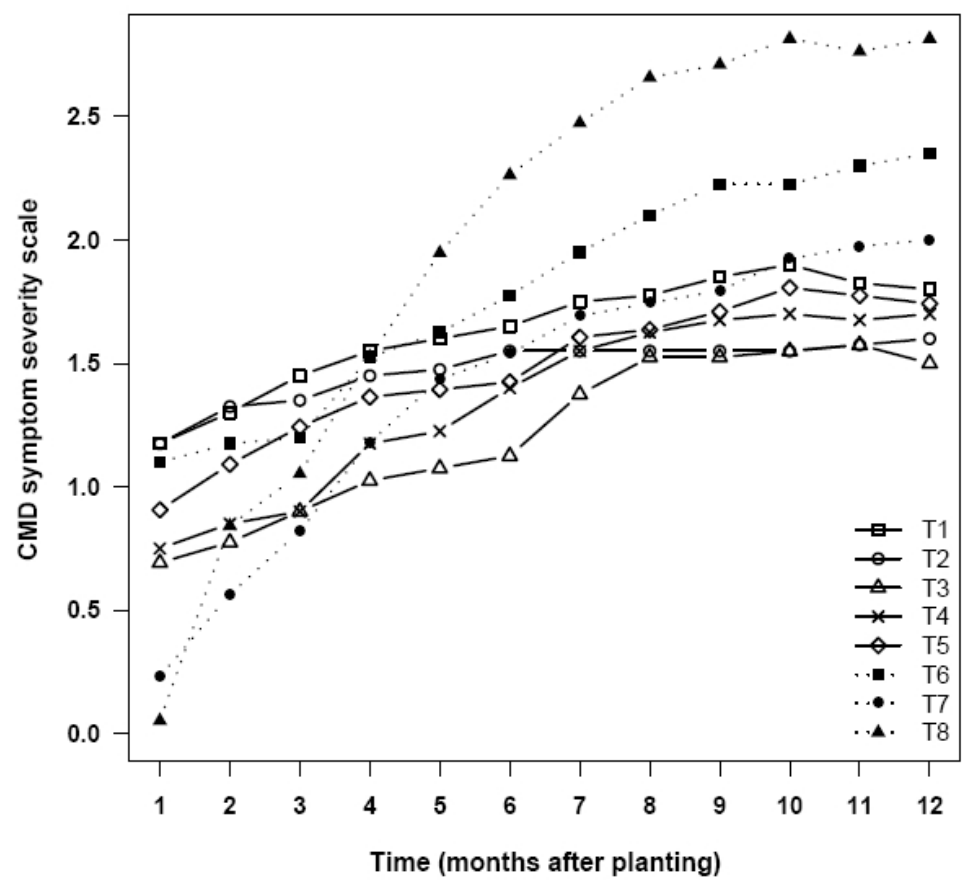

Fig. 3. Average scores of cassava mosaic disease (CMD) symptom severity in heattreated diseased cuttings of a local cv. 'Yalipé' in the 12 months after planting at Kapou in the Central African Republic (2010/2011)

T1: diseased cuttings treated at $43^{\circ} \mathrm{C}, T 2: 45^{\circ} \mathrm{C}, T 3: 47^{\circ} \mathrm{C}, T 4: 49^{\circ} \mathrm{C}, T 5: 51^{\circ} \mathrm{C}, \mathrm{T} 6$ : untreated diseased cuttings, T7: untreated symptomless cuttings, and T8: healthy cassava $\mathrm{cv}$. from Reunion Island free from CMD used as control.

\subsection{Discussion}

Our results demonstrate that hot-water treatment of CMD diseased cuttings at $47^{\circ} \mathrm{C}$ and $49^{\circ} \mathrm{C}$ for 30 minutes has a significantly positive effect on the regeneration of symptomless cassava plants and reduces the severity of symptoms, without affecting the survival of the cuttings. Indeed, with these treatments, one month after planting, up to $40 \%$ of the plants were symptomless compared to only $7 \%$ of the untreated diseased cuttings control. However, none of the temperatures tested led to complete elimination of the symptoms or even to reach the healthy plant rates obtained from control cuttings $(77 \%$ and $93 \%$ healthy plants grown from symptomless cuttings of the local cultivar and healthy cuttings from Reunion Island that were free of CMD, respectively). These results are in agreement with those obtained by [11] who concluded that although hot water treatment of cassava cuttings has beneficial effects, the effects are not therapeutic. In contrast to untreated diseased cuttings which reached $100 \%$ of diseased plants two MAP, the diseased cuttings treated at $47^{\circ} \mathrm{C}, 49^{\circ} \mathrm{C}$ and $51^{\circ} \mathrm{C}$ reached $100 \%$ incidence of CMD only eight MAP. Moreover, in our study, at 12 MAP, all plants grown from diseased cuttings treated at temperatures above $43^{\circ} \mathrm{C}$ expressed significantly less severe symptoms of CMD than untreated diseased 
cuttings. Considering the delay in reaching high CMD incidence or the less severe symptoms of CMD, our results confirm that heat treatment stimulates plant resistance to CMD $[11,18,15]$. Similar reductions in the severity of CMD symptoms after heat treatment were observed by Kwabena team [15] in a local cultivar in Ghana. The effect of temperature was associated with RNA silencing. Drastic elevation of virus-derived short-interfering RNA (siRNA) accumulation was measured with increasing temperature, resulting in reduced development of symptoms [18]. In our study, the highest yield was obtained from plants grown from diseased cuttings treated at $49^{\circ} \mathrm{C}(4.7 \mathrm{~kg} / \mathrm{plant})$, a yield statistically similar to that of untreated symptomless cuttings $(4.6 \mathrm{~kg} / \mathrm{plant})$. Although plants grown from diseased cuttings treated at $47^{\circ} \mathrm{C}, 49^{\circ} \mathrm{C}$ and $51^{\circ} \mathrm{C}$ had a similar CMD incidence at one MAP $(61 \%$, $59 \%$ and $57 \%$, respectively), the diseased cuttings treated at $49^{\circ} \mathrm{C}$ showed significantly lower CMD incidence between two and five MAP compared to plants in the two other treatments. Therefore, our results suggest that the lower incidence and severity of the disease during the first months of plant growth has a significant effect on the final yield. These observations are consistent with previous field experiments in which the yield of cassava decreased dramatically when the infection occurred early and when the severity of symptoms increased [12].

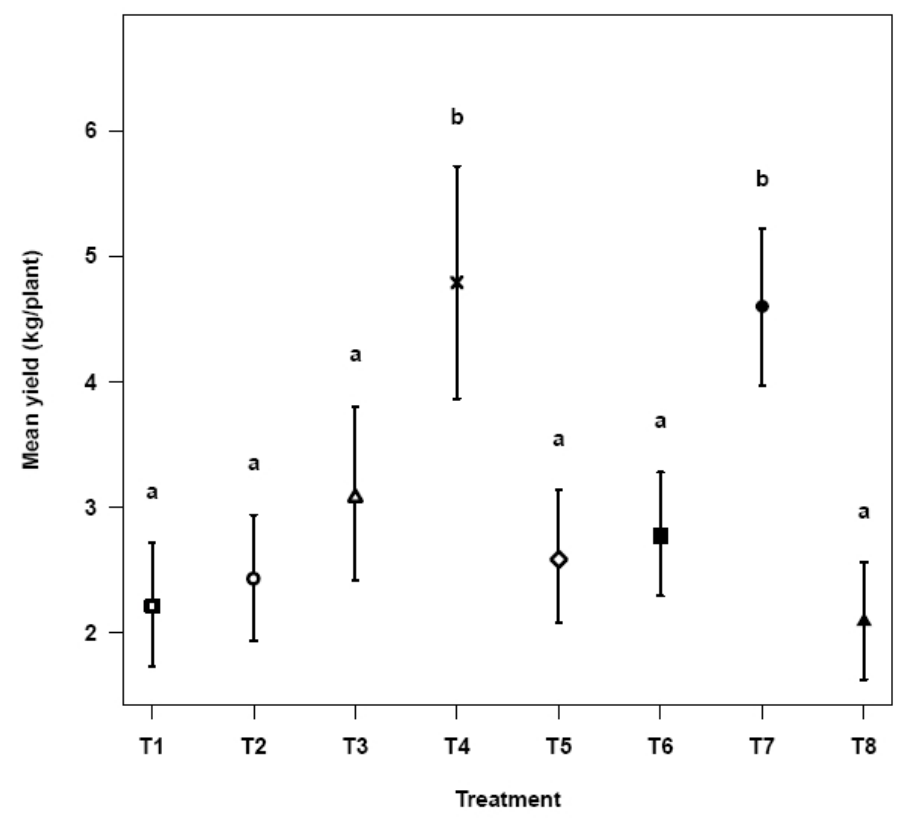

Fig. 4. Mean yield of fresh tuberous roots per cassava plant from heat-treated cassava mosaic diseased cuttings of a local cv. 'Yalipé' in the 12 months after planting at Kapou in the Central African Republic (2010/2011)

T1: diseased cuttings treated at $43^{\circ} \mathrm{C}, T 2: 45^{\circ} \mathrm{C}, T 3: 47^{\circ} \mathrm{C}, T 4: 49^{\circ} \mathrm{C}, \mathrm{T5}: 51^{\circ} \mathrm{C}$, T6: untreated diseased cuttings, T7: untreated symptomless cuttings, and T8: healthy cassava $\mathrm{cv}$. from Reunion Island free from cassava mosaic disease used as control

\section{CONCLUSION}

From our results, it is clear that farmers would benefit from growing heat-treated cuttings of local cultivars, especially in the Central African Republic where the majority of cuttings used by farmers are contaminated by CMD [23]. This technique is therefore appropriate for local 
cultivars which are generally susceptible to CMD and is also appropriate for the agroecological conditions of the country and the tastes and customs of the farmers. Cheap and easy to implement, this technique is an underestimated cultivation practice that should be combined with all existing phytosanitary measures to control CMD in Africa such as the spread of mosaic-free cuttings, roguing of diseased plants, and deployment of resistant cultivars $[12,14]$.

\section{ACKNOWLEDGMENTS}

This study was supported by the Coopération pour la Recherche Universitaire et Scientifique (CORUS), a programme of the Ministère Français des Affaires Etrangères et Européennes (MAEE), CIRAD, the French Embassy in Bangui (CAR), Région Réunion and European Union (ERDF). We express our gratitude to Jean-Philippe Deschamps (SCAC-French Embassy), Emmanuelle Muller (CIRAD-UMR BGPI), Marie-France Duval (CIRAD-UMR AGAP), Yves Lemoine (UTSL) and Jean-Laurent Syssa Magalé (Dean of the Faculty of Science, University of Bangui) for their help in managing the funding of this project.

\section{COMPETING INTERESTS}

Authors have declared that no competing interests exist.

\section{REFERENCES}

1. FAOSTAT, Food and Agriculture Organization of the United Nations. FAO database. Internet. Available: http://faostat.fao.org/site/567/default.aspx\#ancor; 2011.

2. Legg JP, Jeremiah SC, Obiero HM, Maruthi MN, Ndyetabula I, Okao-Okuja G, Bouwmeester H, Bigirimana S, Tata-Hangy W, Gashaka G, Mkamilo G, Alicai T, Kumar PL. Comparing the regional epidemiology of the cassava mosaic and cassava brown streak virus pandemics in Africa. Virus Res. 2011;159:161-170.

3. Harrison BD, Zhou X, Otim-Nape GW, Liu Y, Robinson DJ. Role of a novel type of double infection in the geminivirus-induced epidemic of severe cassava mosaic in Uganda. Ann. Appl. Biol. 1997;131, 437-448.

4. Fondong V, Thresh JM, Fauquet C. Field experiments in Cameroon on cassava mosaic virus disease and the reversion phenomenon in susceptible and resistant cassava cultivars. Int. J. Pest Manag. 2000;46:211-217.

5. Owor B, Legg JP, Okao-Okuja G, Obonyo R, Ogenga-Latigo, MW. The effect of cassava mosaic geminiviruses on symptom severity, growth and root yield of a cassava mosaic virus disease-susceptible cultivar in Uganda. Ann. Appl. Biol. 2004;145:331-337.

6. Owor B, Legg JP, Okao-Okuja G, Obonyo R, Kyamanywa S, Ogenga-Latigo MW. Field studies of cross protection with cassava mosaic geminiviruses in Uganda. J. Phytopathol. 2000b;152:243-249.

7. Legg JP, Owor B, Sseruwagi $P$, Ndunguru J. Cassava mosaic virus disease in East and Central Africa: Epidemiology and management of a regional pandemic. Adv. Virus Res. 2006;67:355-418.

8. Zinga I, Nguimalet CR. Lakouetene DP, Konate G, Kosh Komba E, Semballa S. Les effets de la mosaïque africaine du manioc en République Centrafricaine. Geol. Eco. Trop. (in French). 2008;32:47-60.

9. Patil BL, Fauquet, CM. Cassava mosaic geminiviruses: Actual knowledge and perspectives. Mol. Plant Pathol. 2009;10:685-701. 
10. Kartha K, Gamborg O. Elimination of cassava mosaic disease by meristem culture. Phytopathology. 1975;65:826-828.

11. Kaiser WJ, Louie R. Heat therapy of cassava infected with African cassava mosaic disease. Plant Dis. 1982;66:475-477.

12. Fargette D, Fauquet C, Grenier E, Thresh JM. The spread of an African cassava mosaic virus into and within cassava fields. J. Phytopathol. 1990;130:289-302.

13. Fauquet C, Fargette D. African cassava mosaic virus: Etiology, epidemiology and control. Plant Dis. 1990;74:404-411.

14. Thresh JM, Cooter, RJ. Strategies for controlling cassava mosaic virus disease in Africa. Plant Pathol. 2005;54:587-614.

15. Kwabena A. Use of tissue culture and thermotherapy. Accra, GH, College of Agriculture and Natural Resources, PhD Thesis. Internet Resource.

Available: http://opus.kobv.de/btu/volltexte/2009/782/pdf/Thesis pdf.pdf; 2009.

16. Adejare GO, Coutts RHA. Eradication of cassava mosaic disease from Nigerian cassava clones by meristem-tip culture. Plant Cell Tiss. Organ Cult. 1981;1:25-32.

17. Szittya G, Silhavy D, Molnár A, Havelda Z, Lovas Á, Lakatos L, Bánfalvi Z, Burgyán J. Low temperature inhibits RNA silencing-mediated defence by the control of siRNA generation. EMBO J. 2003;22:633-640.

18. Manganaris GA, Economou A, Boubourakas I, Katis, N. Elimination of PPV and PNRSV through thermotherapy and meristem-tip culture in nectarine. Plant Cell Rep. 2003;22:195-200.

19. Chellappan $\mathrm{P}$, Vanitharani $\mathrm{R}$, Ogbe $\mathrm{F}$, Fauquet $\mathrm{CM}$. Effect of temperature on geminivirus-induced RNA silencing in plants. Plant Physiol. 2005;138:1828-1841.

20. Mallouhi N, Kafara JM. Note de synthèse sur la culture du manioc en Centrafrique. ICRA. (In French). 2002;153.

21. Achidi AU, Ajayi OA, Bokanga M, Maziya-Dixon B. The use of cassava leaves as food in Africa. Ecol. Food. Nutr. 2005;44:423-435.

22. Zinga I, Harimalala M, De Bruyn A, Hoareau M, Semballa S, Reynaud B, Lefeuvre P, Lett JM. East African cassava mosaic virus-Uganda (EACMV-UG) and African cassava mosaic virus (ACMV) reported for the first time in Central African Republic and Chad. New Dis. Rep. 2012;26:7.

23. Zinga I, Chiroleu F, Legg J, Lefeuvre P, Kosh Komba E, Semballa S, Yandia PS, Mandakombo NB, Reynaud B, Lett, JM. Epidemiological assessment of cassava mosaic disease in Central African Republic reveals the importance of mixed viral infection and poor health of plant cuttings. Crop Prot. 2012a;44:6-12.

24. Cours G. Le manioc à Madagascar. Mém. Inst. Scient. Madagascar, Sér. B Biol. Vég. (In French). 1951;3:203-416.

25. Sseruwagi P, Sserubombwe WS, Legg JP, Ndunguru J, Thresh JM. Methods of surveying the incidence and severity of cassava mosaic disease and whitefly vector populations on cassava in Africa: a review. Virus Res. 2004;100:129-142.

26. Holm S. A simple sequentially rejective multiple test procedure. Scand. J. Stat. 1979;6:65-70.

(c) 2014 Zinga et al.; This is an Open Access article distributed under the terms of the Creative Commons Attribution License (http://creativecommons.org/licenses/by/3.0), which permits unrestricted use, distribution, and reproduction in any medium, provided the original work is properly cited.

Peer-review history:

The peer review history for this paper can be accessed here: http://www.sciencedomain.org/review-history.php? $\mathrm{iid}=539 \& i d=2 \&$ aid $=4648$ 